\title{
JOB INSECURITY, LEADERSHIP EMPOWERMENT BEHAVIOUR, EMPLOYEE ENGAGEMENT AND INTENTION TO LEAVE IN A PETROCHEMICAL LABORATORY
}

\author{
Authors: \\ Sonet van Schalkwyk ${ }^{1}$ \\ Danie H. du Toit ${ }^{2}$ \\ Adriaan S. Bothma ${ }^{2}$ \\ Sebastiaan Rothmann ${ }^{2}$

\section{Affiliations:} \\ ${ }^{1}$ Human Resource \\ Department, Sasol, \\ Sasolburg, South Africa \\ ${ }^{2}$ School of Behavioural \\ Sciences, North-West \\ University, South Africa
}

\section{Correspondence to:}

Sebastiaan Rothmann

email:

ian@ianrothmann.com

\section{Postal address:}

PO Box 8060, Swakopmund,

Namibia

\section{Keywords:}

Employee engagement; employee motivation;

leadership; job insecurity; turnover intention

\section{Dates:}

Date Received: 07 July 2009

Date Accepted: 28 Jan. 2010

Dates Published: 06 July 2010

How to cite this article: Van Schalkwyk, S., Du Toit, D.H., Bothma, A.S., \& Rothmann, S. (2010). Job insecurity, leadership empowerment behaviour, employee engagement and intention to leave in a petrochemical laboratory. SA Journal of Human Resource Management/SA Tydskrif vir Menslikehulpbronbestuur, 8(1), Art. \#234, 7 pages. DOI: 10.4102/sajhrm.v8i1.234

\section{This article is available} at:

http://www.sajhrm.co.za

\author{
(C) 2010. The Authors. \\ Licensee: OpenJournals \\ Publishing. This work \\ is licensed under the \\ Creative Commons \\ Attribution License.
}

\begin{abstract}
Orientation: Engaging individuals at work plays an important role in retaining them. Job security and leadership empowerment behaviour are antecedents of employee engagement.

Research purpose: The objective of this study was to investigate the relationship between job insecurity, leadership empowerment behaviour (as perceived by the employees who report to leaders), employee engagement and intention to leave their jobs in a petrochemical laboratory.

Motivation for the study: Knowledge of the effects of job insecurity and leadership on employee engagement and turnover intention will contribute to improved talent management.

Research design, approach and method: A correlational design was used. A total of 169 employees in a petrochemical laboratory were studied. The measuring instruments included the Job Insecurity Index, the Leadership Empowerment Behaviour Questionnaire, and the Utrecht Work Engagement Scale. Two questions were used to measure intention to leave.

Main findings: The results showed that job insecurity was not statistically significantly related to employee engagement and turnover intention. Leadership empowerment behaviour contributed statistically significantly to employee engagement and low turnover intention. Employee engagement partially mediated the relationship between leadership empowerment behaviour and turnover intention.
\end{abstract}

Practical implications: Leaders should be developed to show empowerment behaviour, because it affects employee engagement, which in turn affects their turnover intention.

Contribution: This was the first study that demonstrated the effect of empowerment behaviour of leaders on the engagement and turnover intention of employees.

\section{INTRODUCTION}

Despite South Africa's potential to compete globally, numerous challenges remain. Skills shortages and the high unemployment rate have had a negative impact on the availability of competent people in the country. Staff costs are rising because of the shortage of skilled individuals and the "brain drain' characterised by the emigration of highly skilled people to Europe, the United States of America and Australia (Peralta \& Stark, 2006). The chemical industry is faced with the challenge of retaining talented employees, especially among the previously disadvantaged groups (Peralta \& Stark, 2006). Engaging the individuals at work plays an important role in retaining them.

Employee engagement is influenced by work-related factors (Schaufeli \& Bakker, 2004). Two specific factors are relevant for the purposes of this study, namely the empowerment of employees by leaders and job security. According to Randolph $(1995$, p. 5), the earlier view on management, that is to say 'the manager in control and the employee being controlled', has become obsolete. In traditional organisations, managers were regarded as the sole holders of authority, employees were expected to fulfil rule-bound tasks without questioning (Cunningham, Hyman \& Baldry, 1996); leaders influenced, rather than empowered, their subordinates (Kark, Shamir \& Chen, 2003). It is necessary to move from this traditional, hierarchical, position-based leadership found in many organisations and to propel it toward a leadership style that allows for the empowerment of employees (Carson \& King, 2005). Furthermore, job insecurity increased as a result of economic recessions, new information technology, industrial restructuring and accelerated global competition (De Witte, 2000; Greenhalgh \& Rosenblatt, 1984; Hartley, Jacobson, Klandermans \& Van Vuuren, 1991; Rothmann \& Cooper, 2008).

Job insecurity could threaten the satisfaction of extrinsic needs of employees because of the possible loss of steady income (Siegrist et al., 2004). It could also threaten the satisfaction of intrinsic needs of employees, including autonomy, competence, and relatedness (Ryan \& Deci, 2001). According to Ryan and Deci (2001), secure attachments foster the well-being of employees because they represent secure relationships within which a person satisfies needs for autonomy, competence, and relatedness. Employee engagement is a specific type of well-being that is strongly influenced by the intrinsic motivation of individuals. Bosman, Buitendach and Rothmann (2005) found job insecurity to be negatively related to employee engagement.

Furthermore, the social context in organisations has been consistently connected to individual wellbeing. Other people at work, especially the leader (or supervisor), can affect the way individuals feel about themselves and their work. Poor supervisor-subordinate relationships, poor communication, 
as well as a lack of feedback, impact negatively on the well-being of employees (May, Gilson \& Harter, 2004). In a longitudinal study, Van Dierendonck, Haynes, Borrill and Stride (2004) showed that leadership behaviour affects the well-being of employees; if leader behaviour is supportive and trustworthy in nature it is likely to produce feelings of safety at work (May et al., 2004), which will contribute to employee engagement.

Employee turnover could have a negative effect on organisational effectiveness (Hom \& Griffeth, 1995; Hom \& Kinichi, 2001). The importance of understanding staff turnover in the chemical industry is evident when the contest for talented employees between companies is considered. By identifying the determinants of employees' intention to leave, turnover behaviours could be predicted more precisely and measures to prevent turnover could be taken in advance (Hwang \& Kuo, 2006). Low employee engagement results in intention to leave (Firth, Mellor, Moore \& Loquet, 2004; Harter, Schmidt \& Hayes, 2002).

Therefore, research is necessary regarding the relationship between job insecurity, leadership empowerment behaviour employee engagement and turnover intention. However, no studies were found that specifically examined the relationship between these factors. The objective of this study was to investigate the relationship between leadership empowerment behaviour (as perceived by the employees reporting to them), job insecurity, employee engagement and intention to leave in a petrochemical laboratory.

\section{Job insecurity}

Job insecurity can be conceptualised as the overall concern about the future of one's job (Hartley et al., 1991). It comprises two components, namely the recognition of threats to job security and the concern about these threats (Van Wyk, 2007). The likelihood of job loss refers to the cognitive aspect of job insecurity, while the fear of job loss is related to the affective aspect thereof (De Witte, 2000). The cognitive appraisal of the future situation, whether certain or uncertain, triggers emotions based on the meaning connected to the potential job loss (De Witte, 2000).

Job insecurity is a chronic job stressor (Mauno, Leskinen \& Kinnunen, 2001), which impacts on the well-being of employees (Hellgren, Sverke \& Isaksson, 1999). Employee job insecurity has a detrimental effect on the organisation (Holm \& Hovland 1999). Employees who experience job insecurity are less supportive of organisational goals and do not make an effort to deliver quality work (Greenhalgh \& Rosenblatt, 1984; Sparks, Faragher \& Cooper, 2001). Holm and Hovland (1999) point out that job insecurity results in an increased employee turnover rate.

Leaving the organisation in search of more secure career opportunities is common among employees who feel insecure about their jobs (Ashford, Lee \& Bobko, 1989). This appears to be true, especially among high performers who typically have an easier time securing new employment. The result of increased turnover is an increased cost in terms of the recruitment and training of new employees. Organisations may consequently lose their most valuable employees - the ones they most want to retain (Ashford et al., 1989). The association between job insecurity and intention to leave has been well established in previous studies (Burke, 1998; Mauno et al., 2001). Job insecurity probably affects turnover through a reduced engagement on the part of employees (Mauno et al, 2001).

\section{Leadership empowerment behaviour}

Empowerment is characterised by the redistribution, or devolution, of decision-making power to those who do not currently have it, and gives employees the power to do the job their positions demand (Carson \& King, 2005; Cunningham et al., 1996; Johnson, 1994). Empowered employees become active problem solvers who contribute to the planning and execution of tasks (Cunningham et al., 1996). Therefore, the types of behaviours that leaders utilise requires attention (Arnold, Arad, Rhoades \& Drasgow, 2000). According to Johnson (1994), leadership empowerment behaviour creates an environment that fosters success, because employees are empowered through greater responsibility, decision-making authority, information and feedback, as well as motivation, support and encouragement.

According to Konczak, Stelly and Trusty (2000), leadership empowerment behaviour includes six dimensions: delegation of authority, accountability for outcomes, self-directed decisionmaking, information sharing, skill development, and coaching for innovative performance.

Delegation of authority entails that the leader grant power to subordinates. Delegation of authority should increase intrinsic task motivation by influencing task assessments related to psychological empowerment (Thomas \& Velthouse, 1990). Accountability for outcomes concerns the leader's emphasis on the taking of responsibility for consequences. Empowerment redistributes power and provides a mechanism by which responsibility for performance is transferred to individuals. Self-directed decision-making entails that the leader encourages independent decision-making. Information-sharing entails that leaders share information and knowledge that enables employees to contribute optimally to organisational performance. Skills development concerns the leader's facilitating (rather than directing and/or controlling) of skills development and securing the appropriate training of employees (Wellins, Byham \& Wilson, 1991). Coaching for performance is related to behaviour that encourages calculated risk-taking and new ideas and that provides performance feedback to employees, treating their mistakes and setbacks as opportunities to learn (Konczak et al., 2000).

The relationship with one's leader can have an effect on perceptions of the safety of the work environment. A supportive leader who displays concerns for employees' needs and feelings, who provides positive feedback and encourages employees to voice their concerns, who develops employees' skills and solves their work-related problems, will enhance the self-determination of employees and their interest in their work (May et al., 2004; Ryan \& Deci, 2001). Such individuals will feel safer in engaging in their work.

\section{Employee engagement}

Employee engagement is an important concept for organisations, because it predicts productivity, job satisfaction, motivation, commitment, and low turnover intention (Bakker, Demerouti \& Schaufeli, 2003; Bakker, Schaufeli, Leiter \& Taris, 2008). Employee engagement is defined as 'a positive, fulfilling, workrelated state of mind that is characterised by vigour, dedication, and absorption' (Schaufeli, Salanova, González-Romá \& Bakker, 2002, p. 74). High energy levels and mental resilience while working denote vigour. It entails willingness to invest effort in one's work and to persevere when challenges arise. Dedication refers to deriving a sense of significance from one's work, as well as feeling enthusiastic, inspired and proud. Absorption means to be happily immersed in one's work. Haudan and MacLean (2002) describe engagement as a sustained connection and undivided concentration, where time seems unimportant and the hearts and minds of employees are involved. According to Schaufeli et al. (2002), engagement is not a momentary and specific state, but rather a persistent and pervasive affectivecognitive state, not focused on any particular object, event, individual or behaviour.

Engagement is a positive experience in itself (Schaufeli et al., 2002) and has positive consequences for the organisation, 
as it is generally believed that a relationship exists between employee engagement and business results (Harter et al., 2002). The concept is therefore relevant for employee well-being and work behaviour and is beneficial to the organisation as it is a significant predictor of employees' intention to leave their organisation (Saks, 2006).

\section{Intention to leave}

Vandenberg and Nelson (1999, p. 1315) define intention to leave as an 'individual's own estimated probability (subjective) that they are permanently leaving the organization at some point in the near future'. The determinants of employee turnover have great relevance to the employee who is thinking about quitting, as well as for the manager who is faced with the lack of employee continuity, the high costs involved in the induction and training of new personnel and the issue of organisational productivity (Firth et al., 2004; Siong, Mellor, Moore \& Firth, 2006). According to McCarthy, Tyrrell and Lehane (2007), intentions are the most immediate determinants of actual behaviour. They are therefore accurate indicators of subsequent behaviour, however the reasons for these intentions are often unknown (Firth et al., 2004). Van Dick et al. (2004) agree that the phenomenon is far from being fully understood, especially because some of the psychological processes underlying the withdrawal from the organisation are still unclear.

Intention to leave is related to actual turnover (Firth et al., 2004; McCarthy et al., 2007). Tjeku (2006) reported a relationship between leadership empowerment behaviour and job insecurity. Maré (2007) established a correlation between leadership empowerment behaviour and intention to leave. Mauno et al. (2001) found a relationship between job insecurity and engagement. Burke (1998) and Williams (2003) found a correlation between job insecurity and intention to leave. Saks (2006) reported a relationship between engagement and intention to leave.

Because the work situation is an important context for generating engagement, and previous research has shown that job insecurity might threaten the satisfaction of the extrinsic and intrinsic needs of employees (Ryan \& Deci, 2001; Siegrist et al., 2004), it is expected that job insecurity will result in lower engagement. Furthermore, low leadership empowerment behaviour might threaten the secure relationships (and consequently the psychological safety) of employees, which in turn could result in lower engagement (May et al., 2004; Ryan \& Deci, 2001).

Based upon the above discussion, the following hypotheses were formulated:

Hypothesis 1: Job security and leadership empowerment behaviour predict employee engagement.

Hypothesis 2: Low employee engagement predicts turnover intention.

Hypothesis 3: Employee engagement mediates the relationship between job insecurity and leadership empowerment behaviour on the one hand, and turnover intention, on the other hand.

\section{RESEARCH DESIGN}

\section{Research approach}

This study can be classified as quantitative, because it relies on measurements to compare and analyse different variables. A correlational design was used. Data about job insecurity, the empowerment behaviour of leaders (as perceived by employees who report to them), employee engagement, and turnover intention was collected at a single point in time, with the primary aim of establishing relationships between variables.
TABLE 1

Characteristics of the participants

\begin{tabular}{|c|c|c|c|}
\hline Item & Category & Frequency & $\%$ \\
\hline \multirow[t]{2}{*}{ Gender } & Male & 105 & 62.50 \\
\hline & Female & 63 & 37.50 \\
\hline \multirow[t]{5}{*}{ Age } & 24 years and younger & 29 & 17.30 \\
\hline & $25-35$ years & 75 & 44.60 \\
\hline & $36-45$ years & 33 & 19.60 \\
\hline & $46-55$ years & 24 & 14.30 \\
\hline & 56 years and older & 7 & 4.20 \\
\hline \multirow[t]{6}{*}{ Education level } & Up to grade 12 & 3 & 1.80 \\
\hline & Grade 12 & 88 & 52.40 \\
\hline & Diploma & 54 & 32.10 \\
\hline & Degree & 13 & 7.70 \\
\hline & Postgraduate degree & 9 & 5.40 \\
\hline & Missing values & 1 & 0.60 \\
\hline \multirow[t]{6}{*}{ Job level } & Junior non-management & 43 & 25.60 \\
\hline & Middle non-management & 55 & 32.70 \\
\hline & Senior non-management & 45 & 26.80 \\
\hline & Management & 5 & 3.00 \\
\hline & Senior management & 14 & 8.30 \\
\hline & Missing values & 6 & 3.60 \\
\hline \multirow{6}{*}{$\begin{array}{l}\text { Years of service in } \\
\text { organisation }\end{array}$} & Less than 1 year & 34 & 20.20 \\
\hline & $2-5$ years & 48 & 28.60 \\
\hline & $6-10$ years & 33 & 19.60 \\
\hline & $11-20$ years & 23 & 13.70 \\
\hline & More than 20 years & 29 & 17.30 \\
\hline & Missing values & 1 & 0.60 \\
\hline \multirow{5}{*}{$\begin{array}{l}\text { Years of service in } \\
\text { department }\end{array}$} & Less than 1 year & 27 & 16.10 \\
\hline & $2-5$ years & 48 & 28.60 \\
\hline & $6-10$ years & 30 & 17.90 \\
\hline & $11-20$ years & 33 & 19.60 \\
\hline & More than 20 years & 30 & 17.90 \\
\hline
\end{tabular}

\section{Research method}

\section{Participants}

The participants constituted a convenient sample of employees working in a petrochemical laboratory. A total population of 240 employees was targeted. A response rate of 169 (70.42\%) was achieved, and 168 responses (99\%) could be utilised. Descriptive information of the sample is given in Table 1.

The study population consisted mainly of male $(62.5 \%)$ employees. A total of $44.6 \%$ of the participants were between the ages of 25 and 35. The majority of the participants held either a grade 12 certificate $(52.4 \%)$, or a post-school diploma $(32.14 \%)$. A total of $32.1 \%$ worked in the routine section of the laboratory. Almost one third were on a non-management level, with 2-5 years working experience in the laboratory.

\section{Measuring battery}

A biographical questionnaire was developed to gather information about the demographical characteristics of the participants. Information gathered included age, gender, race, education, and number of years employed.

The Job Insecurity Inventory (JII) (De Witte, 2000) was used to measure job insecurity. Although the JII consists of 11 items, a factor analysis, which was conducted for the purposes of this study, showed that only 9 items loaded significantly on one factor. This factor was labelled 'Job Insecurity'. The items are rated on a Likert scale varying from 1 ('strongly disagree') to 5 ('strongly agree'). Examples of items include: 'I fear that I might get fired' (reversed scored); 'I feel uncertain about the future 
of my job' (reverse scored); and 'I am certain/sure of my job environment'. A Cronbach alpha coefficient of 0.92 was recorded by De Witte (2000). Reynders (2005) obtained an alpha coefficient of 0.82 for the scale. These results confirm the reliability of the JII.

The Leader Empowering Behaviour Questionnaire (LEBQ) (Konczak et al., 2000) was used to measure leadership empowerment behaviour. The scale is one-dimensional but measures six dimensions of leadership empowerment behaviour: the delegation of authority, the emphasis on accountability for outcomes, self-directed decision-making, information sharing, skills development, and coaching for innovative performance. It consists of 19 items that are arranged along a Likert-type scale varying from 1 ('strongly disagree') to 7 ('strongly agree'). Maré (2007) found that the LEBQ consisted of one factor. The LEBQ has shown acceptable internal consistency (Konczak et al., 2000). Tjeku (2006) obtained an alpha coefficient of 0.92 in her study of a South African steel manufacturing organisation.

The Utrecht Work Engagement Scale (UWES) (Schaufeli et al., 2002) was used to measure employee engagement. The scale consists of 17 items that measure vigour (six items), dedication (five items) and absorption (six items). High levels of these three scales indicate that a person experiences a high level of engagement. Items are arranged along a Likert scale varying from 0 ('never') to 6 ('every day'). Examples of items include 'I am enthusiastic about my work' and 'My job inspires me'. For the purposes of this study, a principal factor analysis performed on the 17 items of the UWES resulted in one factor that explained $49.49 \%$ of the total variance. The one-factor structure is supported by Rathbone (2006), who obtained a onefactor structure among employees in the South African mining industry.

Intention to leave was measured by two items, namely 'How often do you think about leaving the job?' and 'How likely are you to look for a new job within the next year?' Items are arranged along a 5-point scale varying from 1 ('very often') to 5 ('rarely or never'). One factor was extracted, explaining 78.68\% of the total variance. Items loading on this factor were related to intention to leave. Firth et al. (2004) obtained a one-factor structure, which supports the findings of this analysis. Firth et al. (2004) have shown that this measure has satisfactory internal reliability estimates $(\alpha=0.75)$.

\section{Research procedure}

The researchers obtained permission from the laboratory management to conduct the study. The researcher administered hard copies of the questionnaires. They were collected directly after they had been completed by the participants. The

TABLE 2

Descriptive statistics, alpha coefficients, and product-moment correlation $s$ of the scales

\begin{tabular}{|c|c|c|c|c|c|c|}
\hline Scale & Mean & s.d. & a & 1 & 2 & 3 \\
\hline 1. Job insecurity & 21.58 & 7.26 & 0.88 & - & - & - \\
\hline $\begin{array}{l}\text { 2. Leadership empowerment } \\
\text { behaviour }\end{array}$ & 99.99 & 25.14 & 0.96 & $-0.23^{*}$ & - & - \\
\hline 3. Employee engagement & 76.04 & 19.36 & 0.93 & -0.15 & $0.39^{*}+$ & - \\
\hline 4. Intention to leave & 5.64 & 2.52 & 0.73 & 0.13 & $-0.36^{\star}+$ & $-0.51^{*}++$ \\
\hline
\end{tabular}

participants completed the questionnaires anonymously. The researchers explained to the participants that the questionnaires would be treated confidentially.

\section{Statistical analysis}

The statistical analysis was carried out with the SPSS (2007) program. Descriptive statistics (e.g. means, standard deviations, skewness and kurtosis) were used to analyse the data. Cronbach alpha coefficients were used to determine the internal consistency of the measuring instruments (Clark \& Watson, 1995). Product-moment correlation coefficients were used to specify the relationships between the variables. In terms of statistical significance, it was decided to set the value at a 95\% confidence interval level ( $p \leq 0.05)$. Effect sizes (Cohen, 1988) were used to determine the practical significance of the findings. A cut-off point of 0.30 (medium effect, Cohen, 1988) was set for the practical significance of correlation coefficients.

A series of multiple regression analyses were performed to test whether job insecurity and leadership empowerment behaviour predict employee engagement and turnover intention and to test whether employee engagement mediates the relationship between job insecurity and leadership empowerment behaviour on the one hand, and turnover intention, on the other hand. Baron and Kenny (1986) recommend three steps to test for mediation. According to these authors, beta coefficients of different regression equations must be compared. Firstly, the mediator should be predicted by the independent variable. Secondly, the dependent variable should be predicted by the mediator and the independent variable and, lastly, the dependent variable should be regressed on the independent variable, controlling for the mediator. If all steps prove significant, perfect mediation holds when controlling for the mediator, the independent variable does not predict the dependent variable.

\section{RESULTS}

\section{Descriptive statistics and correlations}

The descriptive statistics, alpha coefficients, and productmoment correlations of the scales are reported in Table 2.

Table 2 indicates that Cronbach alpha coefficients, varying from 0.73 to 0.96 were obtained. These alpha coefficients were acceptable compared to the guideline of $\alpha>0.70$ (Nunnally \& Bernstein, 1994). Job insecurity was statistically significantly and negatively related to leadership empowerment behaviour. Leadership empowerment behaviour was statistically and practically significantly related to employee engagement (medium effect). Leadership empowerment behaviour was statistically, practically significantly and negatively related to intention to leave (both medium effects). Employee engagement was statistically, practically significantly and negatively related to intention to leave (large effect).

\section{Multiple regression analyses}

Multiple regression analyses were used to test the hypotheses of this study. The results of a multiple regression analysis, with employee engagement as dependent variable, and Job Insecurity and leadership empowerment behaviour as independent variables, are reported in Table 3.

TABLE 3

Multiple regression analysis with leadership empowerment behaviour and job insecurity as independent variables and employee engagement as dependent variable

\begin{tabular}{|c|c|c|c|c|c|c|c|c|c|}
\hline & \multirow[t]{2}{*}{ Model } & \multicolumn{2}{|c|}{ Unstandardised coefficients } & \multirow{2}{*}{$\frac{\text { Standardised coefficients }}{\text { Beta }}$} & \multirow[t]{2}{*}{$t$} & \multirow[t]{2}{*}{$p$} & \multirow[t]{2}{*}{$F$} & \multirow[t]{2}{*}{$R$} & \multirow[t]{2}{*}{$R^{2}$} \\
\hline & & B & s.e. & & & & & & \\
\hline \multirow[t]{3}{*}{1} & (Constant) & 50.37 & 8.54 & & 5.90 & 0.00 & $13.39^{*}$ & 0.39 & 0.15 \\
\hline & Job insecurity & -0.17 & 0.21 & -0.07 & -0.85 & 0.40 & & & \\
\hline & Leader empowerment behaviour & 0.29 & 0.06 & 0.37 & 4.75 & 0.00 & & & \\
\hline
\end{tabular}

${ }^{*} p<0.05 ;$ s.e. $=$ standard error 
TABLE 4

Multiple regression analysis with employee engagement as independent variable and turnover intention as dependent variable

\begin{tabular}{|c|c|c|c|c|c|c|c|c|c|}
\hline & \multirow[t]{2}{*}{ Model } & \multicolumn{2}{|c|}{ Unstandardised Coefficients } & \multirow{2}{*}{$\begin{array}{c}\text { Standardised Coefficients } \\
\text { Beta }\end{array}$} & \multirow[t]{2}{*}{$t$} & \multirow[t]{2}{*}{$p$} & \multirow[t]{2}{*}{$F$} & \multirow[t]{2}{*}{$R$} & \multirow[t]{2}{*}{$R^{2}$} \\
\hline & & B & s.e. & & & & & & \\
\hline \multirow[t]{2}{*}{1} & (Constant) & 1.28 & 0.72 & & 1.77 & 0.08 & $53.06^{*}$ & 0.51 & 0.26 \\
\hline & Employee engagement & -0.07 & 0.01 & -0.51 & -7.29 & $0.00^{*}$ & & & \\
\hline
\end{tabular}

${ }^{*} p<0.05 ;$ s.e. $=$ standard error

Table 3 shows that $15 \%$ of the variance in employee engagement is predicted by job insecurity and leadership empowerment $(F=13.39, p<0.05)$. Only leadership empowerment behaviour contributed statistically significantly to employee engagement $(\beta=0.37)$. This finding provides partial support for Hypothesis 1. It also provides partial evidence for the first requirement when testing for mediation (Baron \& Kenny, 1986), namely that the mediator (employee engagement) should be predicted by the independent variable (leadership empowerment behaviour). However, job insecurity did not statistically significantly predict employee engagement.

The results of a multiple regression analysis with turnover intention as dependent variable, and employee engagement as independent variable, are reported in Table 4.

Table 4 shows that $26 \%$ of the variance in turnover intention is predicted by employee engagement $(F=53.06, p<0.05)$. Employee engagement contributed statistically significantly to low turnover intention $(\beta=-0.51)$. Hypothesis 2 is supported by this finding. Furthermore, it provides evidence for the second requirement for mediation (Baron \& Kenny, 1986), namely that the dependent variable (turnover intention) should be predicted by the mediator (employee engagement).

Next, multiple regression analyses were carried out with turnover intention as dependent variable. In the first step, job insecurity and leadership empowerment behaviour were entered into the regression analysis. In the second step, employee engagement was added as an independent variable. The results are reported in Table 5.

Table 5 shows that $12 \%$ of the variance in turnover intention is predicted by Job insecurity and leadership empowerment behaviour $(F=9.67, p<0.05)$. Leadership empowerment behaviour contributed statistically significantly to low turnover intention $(\beta=-0.32)$. This finding provides evidence for the third requirement for mediation (Baron \& Kenny, 1986) - that the dependent variable (turnover intention) should be predicted by the independent variable (leadership empowerment behaviour).

Table 5 also shows that a statistically significant model $(F=19.20, p<0.05)$ resulted when employee engagement was entered in the second step of the regression analysis. The increase in $R^{2}$ was statistically significant when employee engagement was entered into the regression equation with Job insecurity and leadership empowerment behaviour $\left(\Delta R^{2}=0.16\right)$. The standardised regression coefficient for leadership empowerment behaviour in step 1 of the regression analysis $(\beta=-0.32, p<0.01)$ decreased to $(\beta=-0.16, p<0.05)$ in step 2 . The standardised regression coefficient of employee engagement in step 2 was statistically significant $(\beta=-0.44, p<0.01)$. These results indicate that employee engagement partially mediates the relationship between leadership empowerment behaviour and turnover intention. These findings provide partial support for Hypothesis 3.

\section{DISCUSSION}

The aim of this study was to investigate the relationship between job insecurity, leadership empowerment behaviour, employee engagement and intention to leave in a petrochemical laboratory. The results showed that job insecurity was not statistically significantly related to employee engagement and turnover intention. Leadership empowerment behaviour predicted engagement of employees in the petrochemical laboratory, which in turn predicted low turnover intention of employees. Employee engagement partially mediated the relationship between leadership behaviour and turnover intention.

Pearson correlations were computed to investigate the relationship between the variables. The results showed that leadership empowerment behaviour correlated negatively with job insecurity. This implies that when leadership empowerment behaviour increases, job insecurity decreases. The relationship between leadership empowerment behaviour and job security can be explained as follows: through leadership empowerment behaviour, employees' responsibility and decision-making authority are increased (Johnson, 1994). Furthermore, employees receive information, feedback, motivation, support and encouragement, which results in psychological empowerment (Johnson, 1994) and a reduction in the recognition and concern regarding these threats.

Leadership empowerment behaviour correlated negatively with intention to leave. This implies that when leadership empowerment behaviour increases, intention to leave decreases. Leadership empowerment behaviour entails the delegation of authority, emphasis on accountability for outcomes, self-directed decision-making, information sharing, skill development, and coaching for innovative performance, which result in empowered employees (Konczak et al., 2000). Such a leadership style allows employees freedom to choose the way in which tasks are executed, encourages employees to care about the work they deliver, instils a sense of competence and ensures that their ideas are considered (Appelbaum, Hébert \& Leroux, 1999). This may result in a working environment in which employees feel disinclined to leave the organisation.

TABLE 5

Multiple regression analyses with turnover intention as dependent variable

\begin{tabular}{|c|c|c|c|c|c|c|c|c|c|c|}
\hline & \multirow[t]{2}{*}{ Model } & \multicolumn{2}{|c|}{ Unstandardised Coefficients } & \multirow{2}{*}{$\frac{\text { Standardised Coefficients }}{\text { Beta }}$} & \multirow[t]{2}{*}{$t$} & \multirow[t]{2}{*}{$p$} & \multirow[t]{2}{*}{$F$} & \multirow[t]{2}{*}{$\boldsymbol{R}$} & \multirow[t]{2}{*}{$R^{2}$} & \multirow[t]{2}{*}{$\Delta R^{2}$} \\
\hline & & B & s.e. & & & & & & & \\
\hline \multirow[t]{3}{*}{1} & (Constant) & 3.51 & 1.14 & & 3.07 & 0 & $9.67^{\star}$ & 0.34 & 0.12 & 0.12 \\
\hline & Job insecurity & 0.02 & 0.03 & 0.06 & 0.78 & 0.44 & & & & \\
\hline & Leadership empowerment behaviour & -0.03 & 0.01 & -0.32 & -4.03 & $0.00^{*}$ & & & & \\
\hline \multirow[t]{4}{*}{2} & (Constant) & 0.6 & 1.15 & & 0.52 & 0.60 & 19.2 & 0.53 & 0.28 & 0.16 \\
\hline & Job insecurity & 0.01 & 0.03 & 0.03 & 0.47 & 0.64 & & & & \\
\hline & Leadership empowerment behaviour & -0.02 & 0.01 & -0.16 & -2.05 & $0.04^{*}$ & & & & \\
\hline & Employee engagement & -0.06 & 0.01 & -0.44 & -5.83 & $0.00^{*}$ & & & & \\
\hline
\end{tabular}


Leadership empowerment behaviour showed a positive relationship with employee engagement in this study. Consequently, one may surmise that the empowering behaviour on the part of leaders will result in employees who are able to maintain high energy levels and mental resilience. Employees should be willing to invest effort in their work and persevere when challenges arise; in return, they should derive a sense of significance and experience feelings of enthusiasm, inspiration and pride (Schaufeli et al., 2002). The behaviour which leaders display, which includes sharing power with subordinates (Burke, 1986), emphasising accountability for outcomes, encouraging independent decision-making (Konczak et al., 2000), sharing information and knowledge (Ford \& Fottler, 1995), facilitating skills development (Wellins et al., 1991), encouraging calculated risk taking and new ideas, offering feedback with regard to performance, and treating mistakes and setbacks as opportunities to learn (Konczak et al., 2000) all contribute to employee engagement. Employee engagement is expected to be affected by increasing their self-determination (through satisfaction of their needs for competence, autonomy, and relatedness) (Ryan \& Deci, 2001) and establishing psychological safety (May et al., 2001). A negative relationship was found between engagement and intention to leave. Employees who experience higher levels of engagement are expected to be less inclined to leave the organisation. Schaufeli and Bakker (2004) report that a lower tendency to leave exist among engaged employees (compared to disengaged employees).

The results of the multiple regression analyses showed that $15 \%$ of the variance in employee engagement and $12 \%$ of the variance in turnover intention were predicted by job insecurity and leadership empowerment, but that only leadership empowerment behaviour contributed statistically significantly to employee engagement and turnover intention. Employee engagement predicted $26 \%$ of the variance in turnover intention. It partially mediated the relationship between leadership empowerment behaviour and turnover intention. These findings confirm the effects of leadership empowerment behaviour on both work engagement and turnover intention. It was expected that supportive leader behaviour would contribute to work engagement (May et al., 2004). Secure attachments foster the engagement of employees because they represent secure relationships within which a person satisfies needs for autonomy, competence and relatedness (Ryan \& Deci, 2001).

Although job insecurity was statistically significantly and negatively related to leadership empowerment behaviour, it was not statistically significantly related to employee engagement and turnover intention in this study. Leadership empowerment behaviour shared $5.24 \%$ of the variance with job insecurity. It is possible that a lack of leadership empowerment behaviour contributed to the experiences of job insecurity. Research by May et al. (2004) has shown that the behaviour of leaders can have a negative impact on the psychological safety of employees. However, job insecurity did not affect either the engagement or turnover intention of employees. The finding that job insecurity is not related to employee engagement - is contrary to the finding of Bosman et al. (2005). The difference in the origin of the sample in this study, compared with the origin of the sample in Bosman et al.'s study, might explain the contradictory findings. Bosman et al. (2005) focused on government employees, while this study focused on employees in the private sector.

Leadership empowerment behaviour and engagement were found to be indicators of low intention to leave. This implies that leaders in the organisation should incorporate empowerment behaviours in their management style, and practise these consistently. Attention should be given to the delegation of authority, emphasis on responsibility for outcomes, selfdirected decision-making, skill development, and coaching for innovative performance (Konczak et al., 2000). Leaders who are not competent to demonstrate these behaviours should receive coaching. Leadership empowerment behaviour should also result in decreased levels of job insecurity and increased levels of engagement among employees. It is recommended that the management team of the petrochemical laboratory gain thorough knowledge of the determinants of employees' intention to leave, as outlined in this study. This should enable them to identify turnover behaviours and to implement interventions to retain employees in a proactive manner.

This study had various limitations. Firstly, a correlational design was used, which makes it impossible to assess the causality of relationships. Secondly, self-reports were employed, which limit the responses of the participants to the items used in the scale, which do not capture the richness and variety of possible responses (Sulsky \& Smith, 2005). Lastly, the use of self-report measures is subject to response biases. Participants might have responded to questions in socially appropriate ways.

It is recommended that larger samples with a more powerful sampling method be utilised to enable generalisation of the findings to other similar groups in the petrochemical industry. Also, longitudinal research is recommended to establish whether causal relationships exist among job insecurity, leadership empowerment behaviour, employee engagement and intention to leave.

\section{REFERENCES}

Appelbaum, S.H., Hébert, D., \& Leroux, S. (1999). Empowerment: Power, culture and leadership: A strategy or fad for the millennium? Journal of Workplace Learning: Employee Counselling Today, 11, 233-254.

Arnold, J.A., Arad, S., Rhoades, J.A., \& Drasgow, F. (2000). The empowering leadership questionnaire: The construction and validation of a new scale for measuring leader behaviors. Journal of Organizational Behavior, 21, 249-269.

Ashford, S.J., Lee, C., \& Bobko, P., (1989). Content, causes, and consequences of job insecurity: A theory-based measure and substantive test. Academy of Management Journal, 32, 803-829.

Bakker, A.B., Demerouti, E., \& Schaufeli, W.B. (2003). Dual processes at work in a call centre: An application of the job demands-resources model. European Journal of Work and Organizational Psychology, 12, 393-417.

Bakker, A.B., Schaufeli, W.B., Leiter, M.P., \& Taris, T.W. (2008) Work engagement: An emerging concept in occupational health psychology. Work and Stress, 22, 187-200.

Baron, R.M., \& Kenny, D.A. (1986). The moderator-mediator distinction in social psychological research: Conceptual, strategic, and statistical considerations. Journal of Personality and Social Psychology, 51, 1173-1182.

Bosman, J., Buitendach, J.H., \& Rothmann, S. (2005). Job insecurity, burnout and work engagement: The impact of positive and negative affectivity. South African Journal of Industrial Psychology, 31(4), 48-56.

Burke, R.J. (1998). Correlates of job insecurity among recent business school graduates. Employee Relations, 20(1), 92-99.

Burke, W. (1986). Leadership as empowering others. In S. Srivastva (Ed.), Executive power (pp. 51-77). San Francisco: Jossey-Bass.

Carson, C.M., \& King Jr., J.E. (2005). Conceptual paper. Leaving leadership: Solving leadership problems through empowerment. Management Decision, 43, 1049-1053.

Clark, L.A., \& Watson, D. (1995). Constructing validity: Basic issues in objective scale development. Psychological Assessment, 7, 309-319.

Cohen, J. (1988). Statistical power analysis for the behavioral sciences (2nd edn.). Hillsdale: Lawrence Erlbaum and Associates.

Cunningham, I., Hyman, J., \& Baldry, C. (1996). Empowerment: The power to do what? Industrial Relations Journal, 27(2), 143-154.

De Witte, H. (2000). Arbeidsethos en jobonzekerheid: Meting en gevolgen voor welzijn, tevredenheid en inzet op het werk [Work ethic and job insecurity: Assessment and consequences for well-being, satisfaction and performance at work]. In R. Bouwen, K. de Witte, H. de Witte, \& T. Taillieu (Eds.), Van groep tot gemeenschap [From group to community] (pp. 325-350). Leuven: Garant. 
Firth, L., Mellor, D.J., Moore, K.A., \& Loquet, C. (2004). How can managers reduce employee intention to quit? Journal of Managerial Psychology, 19(2), 170-187.

Ford, R.C., \& Fottler, M.D. (1995). Empowerment: A matter of degree. Academy of Management Executive, 9, 21-28.

Greenhalgh, L., \& Rosenblatt, Z. (1984). Job insecurity: Toward conceptual clarity. Academy of Management Review, 3, 438-448.

Harter, J.K., Schmidt, F.L., \& Hayes, T.L. (2002). Business-unit level relationship between employee satisfaction, employee engagement, and business outcomes: A meta-analysis. Journal of Applied Psychology, 87, 268-279.

Hartley, J., Jacobson, D., Klandermans, B., \& Van Vuuren, T. (1991). Job insecurity: Coping with job at risk. London: Sage Publications.

Haudan, J.A., \& MacLean, D. (2002). ' $E$ ' is for engagement: Transforming your business by transforming your people. Journal of Change Management, 2(3), 1469-7017.

Hellgren, J., Sverke, M., \& Isaksson, K. (1999). A twodimensional approach to job insecurity: Consequences for employee attitudes and well-being. European Journal of Work and Organizational Psychology, 8(2), 179-195.

Holm, S., \& Hovland, J. (1999). Waiting for the other shoe to drop: Help for the job-insecure employee. Journal of Employment Counseling, 36(4), 156-166.

Hom, P.W., \& Griffeth, R.W. (1995). Employee turnover. Cincinnati: South Western College Publishing.

Hom, P.W., \& Kinichi, A.J. (2001). Towards a greater understanding of how dissatisfaction drives employee turnover. Academy of Management Journal, 44, 975-981.

Hwang, I., \& Kuo, J. (2006). Effects of job satisfaction and perceived alternative employment opportunities on turnover intention: An examination of public sector organizations. The Journal of American Academy of Business, $8,254-259$.

Johnson, P.R. (1994). Brains, heart and courage: Keys to empowerment and self-directed leadership. Journal of Managerial Psychology, 9(2), 17-21.

Kark, R., Shamir, B., \& Chen, G. (2003). The two faces of transformational leadership: Empowerment and dependency. Journal of Applied Psychology, 88, 246-255.

Konczak, L.J., Stelly, D.J., \& Trusty, M.L. (2000). Defining and measuring empowering leader behaviors: Development of an upward feedback instrument. Educational and Psychological Measurement, 60, 301-313.

Maré, Z. (2007). Leadership empowerment behaviour, organisational commitment and turnover intention in the gold mining industry. Unpublished master's thesis, North-West University, Potchefstroom, South Africa.

Mauno, S., Leskinen, E., \& Kinnunen, U. (2001). Multi-wave, multi-variable models of job insecurity: Applying different scales in studying the stability of job insecurity. Journal of Organizational Behavior, 22, 919-937.

May, D., Gilson, R., \& Harter, L. (2004). The psychological conditions of meaningfulness, safety and availability and the engagement of the human spirit at work. Journal of Occupational and Organizational Psychology, 77, 11-37.

McCarthy, G., Tyrrell, M.P., \& Lehane, E. (2007). Intention to 'leave' or 'stay' in nursing. Journal of Nursing Management, $15,248-255$.

Nunnally, J.C., \& Bernstein, I.H. (1994). Psychometric theory (3rd edn.). New York: McGraw-Hill.

Peralta, M., \& Stark, A. (2006). South Africa: A crossover from inward thinking to a global outlook. Chemical Week, 168(35), 41-52.

Randolph, W.A. (1995). The leadership challenge of changing to a culture of empowerment. Executive Development, 8(1), 5-8.
Rathbone, A.D. (2006). Work engagement of employees in the mining environment. Unpublished master's thesis, North-West University, Potchefstroom, South Africa.

Reynders, E.F. (2005). Job insecurity, psychological empowerment and engagement in a government organisation. Unpublished master's thesis, North-West University, Vanderbijlpark, South Africa.

Rothmann, S., \& Cooper, C.L. (2008). Organizational and work psychology. London: Hodder Education.

Ryan, R.M., \& Deci, E.L. (2001). On happiness and human potentials: A review of research on hedonic and eudaimonic well-being. Annual Review of Psychology, 52, 141-166.

Saks, A.M. (2006). Antecedents and consequences of employee engagement. Journal of Managerial Psychology, 21, 600-619.

Schaufeli, W.B., \& Bakker, A.B. (2004). Job demands, job resources and their relationship with burnout and engagement: A multi-sample study. Journal of Organizational Behavior, 25, 293-315.

Schaufeli, W.B., Salanova, M., Gozáles-Romá, V., \& Bakker, A.B. (2002). The measurement of engagement and burnout: A two sample confirmatory factor analytic approach. Journal of Happiness Studies, 3, 71-92.

Siegrist, J., Starke, D., Chandola, T., Godin, I., Marmot, M. Niedhammer, I. et al., (2004). The measurement of effortreward imbalance at work: European comparisons. Social Science and Medicine, 58, 1483-1499.

Siong, Z.M.B., Mellor, D., Moore, K.A., \& Firth, L. (2006). Predicting intention to quit in the call centre industry: Does the retail model fit? Journal of Managerial Psychology, 21, 231-243.

Sparks, K., Faragher, B., \& Cooper, C.L. (2001). Well-being and occupational health in the 21st century workplace. Journal of Occupational and Organizational Psychology, 74, 489-509.

SPSS. (2007). SPSS for Windows version 15.0. [Computer software] Chicago: SPSS Inc.

Sulsky, L., \& Smith, C. (2005). Work stress. Belmont: Thomson Wadsworth

Thomas, K.W., \& Velthouse, B.A. (1990). Cognitive elements of empowerment: An 'interpretive' model of intrinsic task motivation. Academy of Management Review, 15, 666-681.

Tjeku, M.S. (2006). Empowerment and job insecurity in a steel manufacturing organisation. Unpublished master's thesis, North-West University, Vanderbijlpark, South Africa.

Vandenberg, R.J., \& Nelson, J.B. (1999). Disaggregating the motives underlying turnover intentions: When do intentions predict turnover behaviour? Human Relations, 52, 1313-1336.

Van Dick, R., Christ, O., Stellmacher, J., Wagner, U., Ahlswede, O., Grubba, C. et al.,(2004). Should I stay or should I go? Explaining turnover intentions with organizational identification and job satisfaction. British Journal of Management, 15, 351-360.

Van Dierendonck, D., Haynes, C., Borrill, C., \& Stride, C. (2004). Leadership behavior and subordinate well-being. Journal of Occupational Health Psychology, 9, 165-175.

Van Wyk, M. (2007). Setting a research agenda for job insecurity in South African organisations. Unpublished master's thesis, North-West University, Potchefstroom, South Africa.

Wellins, R.S., Byham, W.C., \& Wilson, J.M. (1991). Empowered teams. San Francisco: Jossey-Bass.

Williams, S.V. (2003). An empirical investigation of turnover intentions of internal auditors. Dissertation Abstract International Section A: Humanities and Social Sciences, 64(5A), 1741. 